\title{
Flatid Planthopper, Oormenaria rufifascia (Walker) (Insecta: Hemiptera: Auchenorrhyncha: Flatidae) ${ }^{1}$
}

\section{F. W. Howard and Susan Halbert ${ }^{2}$}

\section{Introduction}

Ormenaria rufifascia (Walker) is a common insect on some species of palms in Florida. Although it is usually not a serious pest, it sometimes indirectly causes aesthetic damage when dense populations produce honeydew that supports extensive coatings of sootymold on the host plants. Both the adults and nymphs are conspicuous insects that often arouse people's curiosity.

\section{Distribution}

Ormenaria rufifascia has been reported throughout the Florida peninsula and in Georgia (Mead 1965). It may be presumed to be present, but not recorded, throughout the range of cabbage palmetto and possibly of saw palmetto (i.e., Florida and the Gulf Coast west to Louisiana and the Atlantic Coast north through the Carolinas. It was also reported in Cuba on Colpothrinax wrightii (see Table 1 below) (Metcalf and Bruner 1948). It was not found in a survey of auchenorrhynchous insects on palms in the Dominican Republic (Howard et al. 1981), but an unidentified species of Ormenaria was found on African oil palm, Elaeius guineensis Jacq., in Santo
Domingo (Abud Antón 1982). Ormenaria rufifascia has been intercepted in California on nursery plants shipped from Florida (Anonymous 2003a, Anonymous 2003b), but is not known to have become established in that state.

\section{Description}

Adults: The adults are rather large for planthoppers i.e., about $11 \mathrm{~mm}$ in length. They are highly conspicuous when seen on their usual feeding site, i.e., the abaxial ('lower') surface of fan-leaf palms. Being laterally flattened and deltoid in shape, they appear as tiny colorful sailboats. Their ground-color is light blue-green, with various orange to reddish markings, including two patches on the face near the medial ridge, bands along the dorso-lateral margins of the head, and two longitudinal stripes on the prothorax and mesothorax. The forewings are bordered with orange-yellow. The compound eyes are orange colored (Mead 1965).

Nymphs: The nymphs are light green with faint longitudinal orange stripes. These colors are partially masked by a flocculent wax coating that they secrete.

1. This document is EENY-351 (IN643), one of a series of Featured Creatures from the Entomology and Nematology Department, Florida Cooperative Extension Service, Institute of Food and Agricultural Sciences, University of Florida. Published: July 2005. This document is also available on Featured Creatures Website at http://creatures.ifas.ufl.edu. Please visit the EDIS Website at http://edis.ifas.ufl.edu.

2. F. W. Howard, University of Florida and Susan Halbert, Florida Department of Agriculture and Consumer Services, Division of Plant Industry, Gainesville, FL.

The Institute of Food and Agricultural Sciences (IFAS) is an Equal Opportunity Institution authorized to provide research, educational information and other services only to individuals and institutions that function with non-discrimination with respect to race, creed, color, religion, age, disability, sex, sexual orientation, marital status, national origin, political opinions or affiliations. U.S. Department of Agriculture, Cooperative Extension Service, University of Florida, IFAS, Florida A. \& M. University Cooperative Extension Program, and Boards of County Commissioners Cooperating. Larry Arrington, Dean 


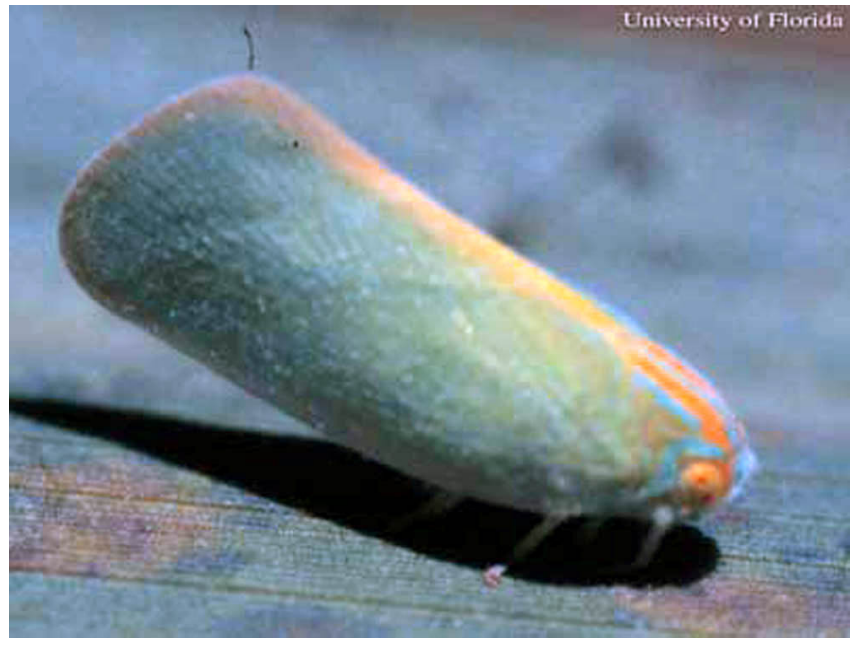

Figure 1. Adult Ormenaria rufifascia (Walker), a flatid planthopper. Credits: F. W. Howard, University of Florida

They drag waxy caudal filaments behind them as they move about the leaf surface.

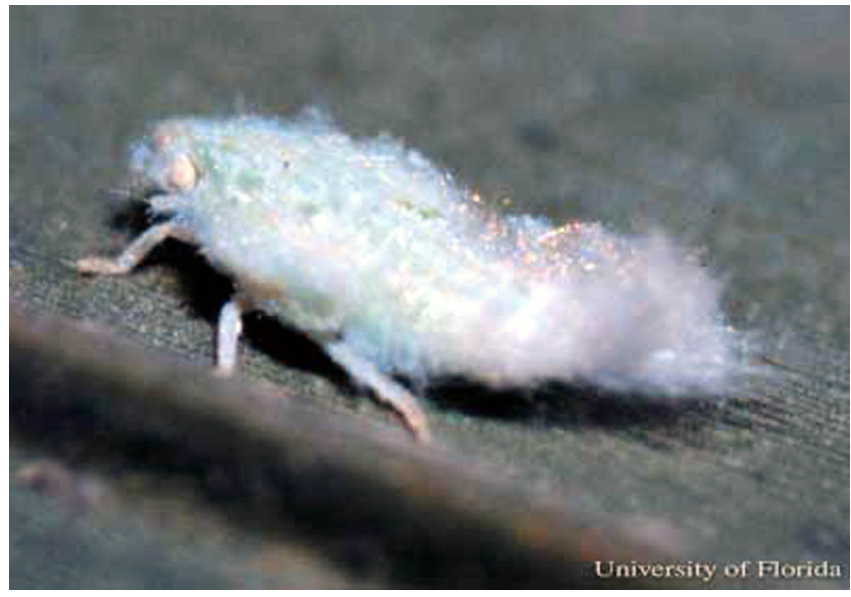

Figure 2. Nymph of Ormenaria rufifascia (Walker), a flatid planthopper. Credits: F. W. Howard, University of Florida

There are no other species of similar appearance known to occur on palms in Florida, and very few species of Flatidae occur on palms anywhere in the world (Howard et al. 2001).

\section{Biology}

Ormenaria rufifascia completes one generation per year. The egg stage of this species has not been observed, but because the females have a sword-like ovipositor typical of auchenorrhynchous insects, they probably insert their eggs into the plant tissue of their hosts. It is believed that like other North American flatids, the females oviposit in late summer and the eggs hatch in January. First instar nymphs have been seen on cabbage palmetto fronds by the second week of January. In southern Florida, nymphs develop to mature adults as early as May. The nymphs undergo five instars, during which they increase from about $1.4 \mathrm{~mm}$ to about $4.7 \mathrm{~mm}$ in length. The mean number of days in each instar on a cabbage palmetto host was 23, 20, 19, 24, 8, and 12 (Wilson and Tsai 1984)

In late spring and early summer, both nymphs and adults are commonly seen together on the abaxial leaf surfaces of the fronds of their palm hosts. During the summer, all nymphs have matured and only adults are seen on palms. Neither nymphs nor adults are present on palms in late summer (Mead 1965)\}.

Both the nymphs and adults tend to occur on older rather than younger leaves, a behavioral trait that is characteristic of many insects that feed on palm leaves. The fact that the older fronds of palms are more or less horizontal and thus offer protection from sun and wind may be a factor in their being preferred by many kinds of insects (Howard et al. 2001).

Populations often consist of a few to several nymphs, adults, or both, but dense populations have been observed. A total of 50 adults on one frond of Pritchardia sp. was reported as an unusually dense population (Mead and Richman 2000), but more recently a total of 238 nymphs and 162 adults were observed on a single frond of a palm, Sabal maritima Howard \& Steinberg, (unpublished).

\section{Host Plants}

The natural hosts of $O$. rufifascia in Florida are probably cabbage palmetto, Sabal palmetto, and saw palmetto, Serenoa repens, both native to this state, but this insect is sometimes seen on other palms. Where many different palms are grown together, such as in botanical gardens, the adults may be observed on a rather large diversity of palm species, but many of these are possibly not more than transitory hosts at best. Palms upon which adults and nymphs have been observed in the same colony can be assumed to support the insect throughout its life cycle and thus may be considered true hosts. These are listed in Table 1.

All listed species of palms are in the subfamily Coryphoideae of the family Palmae. Of the 11 


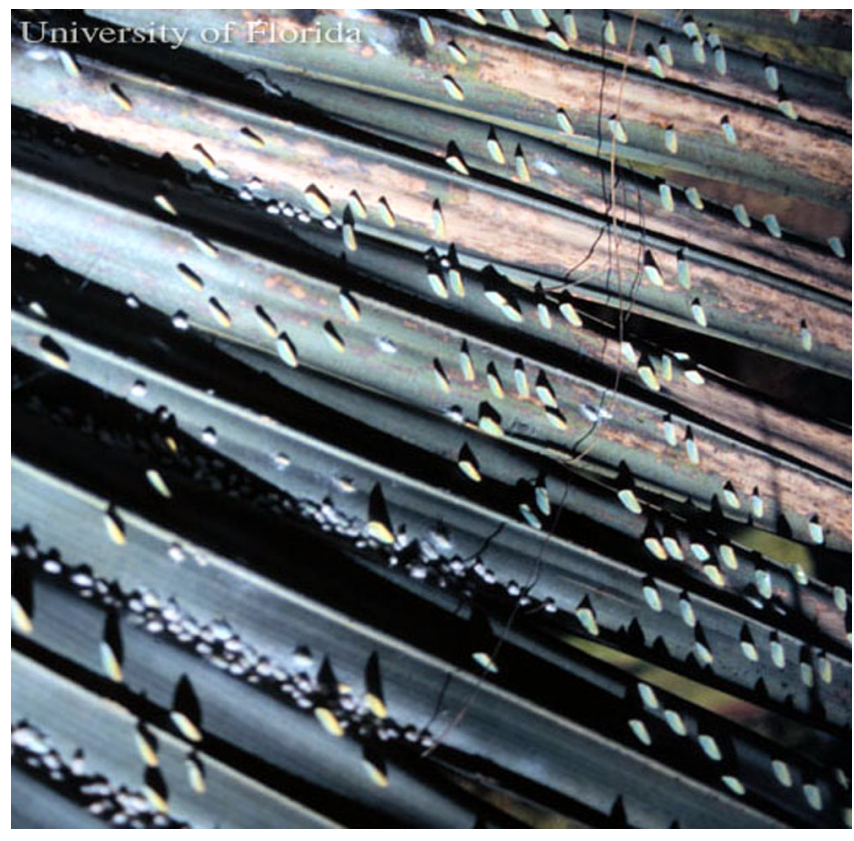

Figure 3. A dense infestation of Ormenaria rufifascia (Walker), a flatid planthopper, on a palm frond. Credits: $F$. W. Howard, University of Florida

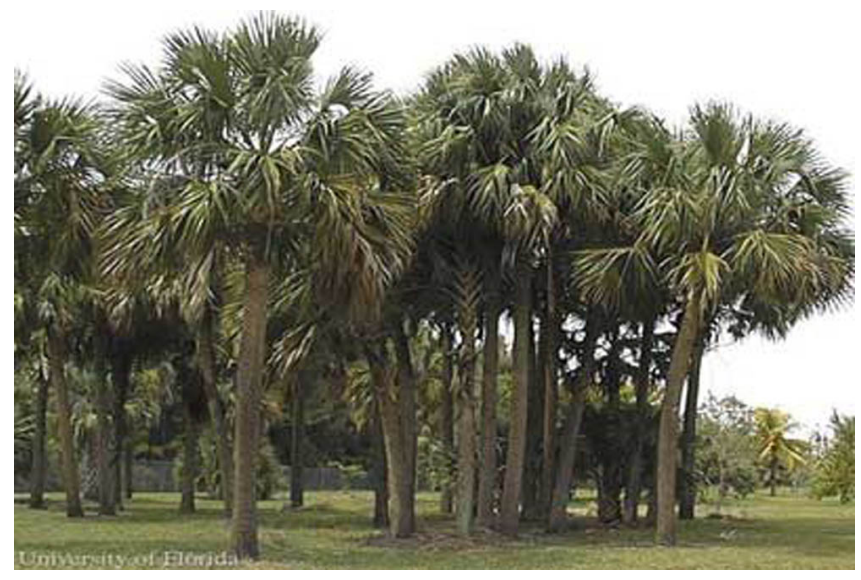

Figure 4. Cabbage palmettos, Sabal palmetto (Walt.) Loddiges. Credits: F. W. Howard, University of Florida

species, nine are native to the Caribbean Floristic Region (which includes Florida), and two are native to the Eastern Hemisphere. The preponderance of American species that serve as hosts may reflect the relatively large proportion of these in landscaped areas and botanical gardens in Florida. The fronds of the different hosts vary in physical characteristics, e.g., color (yellow-green to blue-green and glaucus) and texture of the laminae. The most obvious characteristic common to all is the palmate, rather than pinnate, form of the fronds. Many kinds of insects that occur on palms appear to prefer palms of one or the other of these forms of fronds (Howard et al. 2001).
There is one curious record from Broward County, Florida, of nymphs and adults of $O$. rufifascia on croton, Codiaeum variegatum (L.) A. Juss. (Euphorbiaceae) (Louis Daigle, Broward County Cooperative Extension Service agent, in DPI records).

\section{Damage}

Like the vast majority of species of the insect order Hemiptera, $O$. rufifascia feeds by sucking plant juices, and thus draws energy from the plant. The populations of this insect usually do not consist of more than several individuals per frond, but dense populations, such as that referred to in the paragraph above undoubtedly consume large quantities of juices over time. As evidence, highly infested fronds are sticky with honeydew and support thick crusts of sooty mold.

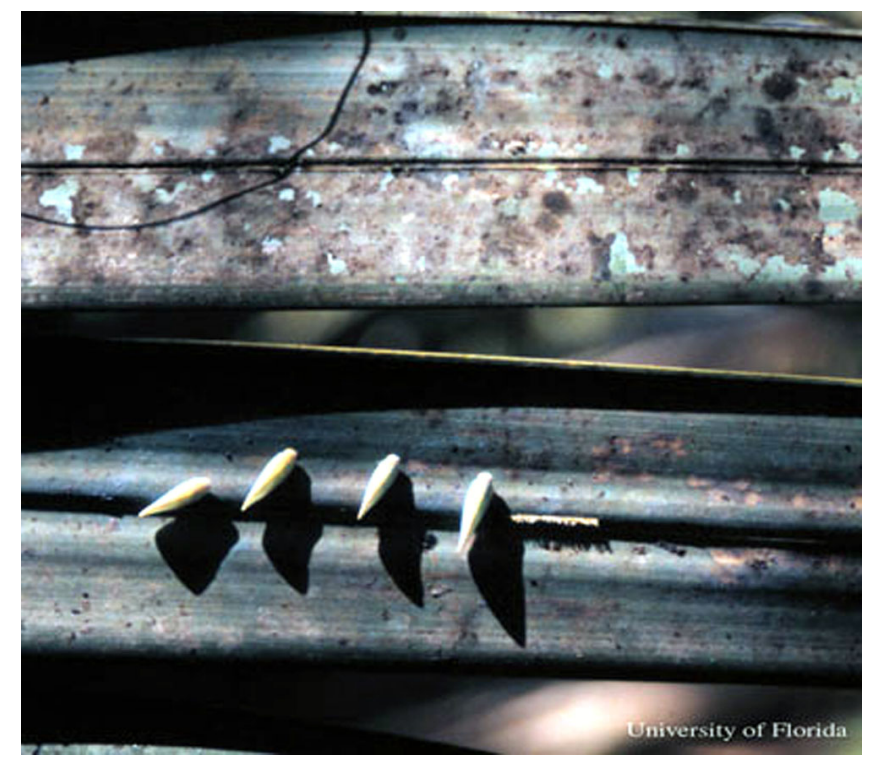

Figure 5. Sooty mold associated with Ormenaria rufifascia (Walker), a flatid planthopper, on a palm frond. Credits: F. W. Howard, University of Florida

\section{Management}

Studies have not been conducted to identify the factors that regulate populations of $O$. rufifascia. A stink bug (Hemiptera: Pentatomidae) has been observed to prey on O. rufifascia (Mead and Richman 2000), but is probably not an important natural enemy of this flatid. In any case, populations of this insect are generally sparse and control measures would seldom be needed. The species has not been 
Table 1. Palm hosts of Ormenaria rufifascia.

\begin{tabular}{|c|c|c|c|}
\hline Species & Common Name* & Native Distribution* & Record \\
\hline 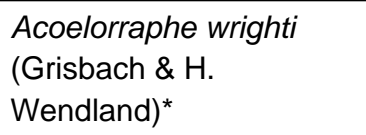 & $\begin{array}{l}\text { Everaglades palm, } \\
\text { Paurotis palm }\end{array}$ & $\begin{array}{l}\text { Florida, Bahamas, Cuba, Yucatan } \\
\text { Peninsula (Mexico), Caribbean } \\
\text { coast of Central America }\end{array}$ & FDACS, DPI** \\
\hline $\begin{array}{l}\text { Colpothrinax wrightii } \\
\text { (Grisebach \& H. A. } \\
\text { Wendland }\end{array}$ & Palma barrigona (Cuba) & $\begin{array}{l}\text { Pinar del Rió and Isla de la } \\
\text { Juventud, Cuba }\end{array}$ & $\begin{array}{l}\text { (Metcalf and Bruner, } \\
\text { 1948) }\end{array}$ \\
\hline $\begin{array}{l}\text { Copernicia berteroana } \\
\text { Beccari }\end{array}$ & $\begin{array}{l}\text { Yarey (Dominican } \\
\text { Republic), Dyaré (Haiti) }\end{array}$ & Hispaniola & FDACS, DPI** \\
\hline $\begin{array}{l}\text { Latania lontaroides } \\
\text { (Gaertner) }\end{array}$ & Red latan palm & Mascarene Islands & FDACS, DPI** \\
\hline $\begin{array}{l}\text { Sabal maritima (Kunth) } \\
\text { Burret }\end{array}$ & $\begin{array}{l}\text { Bull thatch (Jamaica), } \\
\text { palma cana (Cuba) }\end{array}$ & Cuba, Jamaica & $\begin{array}{l}\text { Howard and B. Steingerg } \\
\text { (unpublished) }\end{array}$ \\
\hline $\begin{array}{l}\text { Sabal palmetto (Walt.) } \\
\text { Loddiges }\end{array}$ & Cabbage palmetto & $\begin{array}{l}\text { Bahamas, western Cuba, Florida, } \\
\text { coastal regions of Georgia, and } \\
\text { North and South Carolina }\end{array}$ & FDACS, DPI** \\
\hline Sabal uresana Trelease & $\begin{array}{l}\text { Palma blanca, palma } \\
\text { cana }\end{array}$ & Chihuahua and Sonora (Mexico) & FDACS, DPI ${ }^{* *}$ \\
\hline $\begin{array}{l}\text { Serrenoa repens } \\
\text { (Bartram) Small }\end{array}$ & Saw palmetto & $\begin{array}{l}\text { Florida, coastal plains to Alabama } \\
\text { and Virginia }\end{array}$ & FDACS, DPI** \\
\hline
\end{tabular}

considered economically important enough to justify research on chemical or other methods of controlling it. In cases in which a few specimen palms become highly infested with this insect, it may be possible to eliminate them by simple physical means, such as a strong water spray.

\section{Selected References}

Abud Antón AS. (1982). Plagas de insectos en Elaeis guineensis Jacq. Naturalista Postal (Carta ocasional del Herbario, Universidad de Santo Domingo. http://marcano.freeservers.com/np/np82a. html (24 June 2005).

Anonymous. 2003a. Tulare County Annual Crop and Livestock Report 2002. Tulare County Agriculture Commissioner, Tulare, CA.
Anonymous. 2003b. Santa Barbara County Agricultural Production Report 2002. Agricultural Commission, Santa Barbara County, CA, Santa Barbara, CA.

Henderson A, Galeano G, Bernal R. 1995. Field guide to the palms of the Americas Princeton University Press, Princeton, N. J.

Howard FW, Kramer JP, Féliz Peralta M. 1981. Homópteros auchenorrhyncha asociados á palmeras en un área de la República Dominicana afectada por el amarillamiento letal del cocotero. Folia Entomológica Mexicana 47:37-50.

Howard FW, Moore D, Giblin-Davis RM, Abad RG. 2001. Insects on Palms CABI Publications, Wallingford, UK. 
Jones D. 1995. Palms throughout the World Smithsonian Institution Press, Washington, D. C.

Mead FW. 1965. Ormenaria rufifascia (Walker), a planthopper pest of palms (Homoptera: Flatidae). Florida Department of Agriculture, Division of Plant Industry, Gainesville, FL.

Mead FW, Richman D. (2005). Florida predatory stinkbug, Euthyrhynchus floridanus (Linnaeus) UF/IFAS Featured Creatures. http://creatures.ifas.ufl.edu/beneficial/ e_floridanus.htm (24 June 2005).

Metcalf ZP, Bruner SC. 1948. Cuban Flatidae with new species from adjacent regions. Annals of the Entomological Society of America 41:63-118.

Wilson SW, Tsai JH. 1984. Ormenaria rufifascia (Homoptera: Fulgoroidea: Flatidae): Description of nymphal instars and notes on field biology. New York Entomological Society 92:307-315. 